\title{
An unwanted side effect: Giant hepatocellular carcinoma development after ledipasvir/sofosbuvir therapy in a chronic hepatitis $\mathrm{C}$ virus-induced cirrhotic patient
}

\author{
İstenmeyen bir yan etki: Kronik hepatit $\mathrm{C}$ virüsünün indüklediği sirozlu hastada \\ ledipasvir/sofosbuvir terapisi sonrasında dev hepatosellüler karsinom gelişimi
}

\author{
Tolga Şahin (1), Ayfer Serin (1) \\ Department of Internal Medicine, Division of Gastroenterology, Demiroğlu Bilim University Medicine Faculty, Istanbul, Turkey
}

\begin{abstract}
Hepatocellular carcinoma $(\mathrm{HCC})$ is the fifth common cancer and the second cause of cancer-related death worldwide. Hepatitis $\mathrm{C}$ virus (HCV) is a common cause of chronic hepatitis, liver cirrhosis, and HCC. Recently, some new drugs have been developed named direct-acting antivirals (DAAs) for chronic HCV treatment. Direct-acting antivirals provide sustained viral response and total cure in over $80 \%$ of chronic hepatitis $C$ patients. In this article, we present a patient with HCV genotype $1 \mathrm{~b}$-induced cirrhosis with giant HCC development after ledipasvir/sofosbuvir combination therapy. Although chronic hepatitis $C$ infection can be cured with the combination of new generation DAAs, HCC pathogenesis and development risk in cirrhotic cases are still unclear. Thus, cirrhotic patients treated with DAAs should be followed-up at close intervals after treatment.
\end{abstract}

Keywords: Hepatitis C virus; hepatocellular carcinoma; ledipasvir; sofosbuvir.

$\ddot{O Z z}$

Hepatosellüler karsinom (HSK) dünya çapında en yaygın beşinci kanser ve kanserle ilişkili ölümün ikinci nedenidir. Hepatit $C$ virüsü (HCV) kronik hepatit, karaciğer sirozu ve HSK'nin yaygın bir nedenidir. Kısa zaman önce, kronik HCV tedavisi için doğrudan etkili antiviral (DEA) adlı bazı yeni ilaçlar geliştirilmiştir. Doğrudan etkili antiviraller kronik hepatit $C$ hastalarının \%80'inden fazlasında sürekli viral yanıt ve tam iyileşme sağlar. Bu yazıda, ledipasvir/sofosbuvir kombinasyon terapisi sonrasında dev HSK gelişimi olan HCV genotip 1b'nin indüklediği sirozlu bir hasta sunuldu. Kronik hepatit C enfeksiyonu yeni nesil DEA'ların kombinasyonu ile tedavi edilebilse de sirozlu olgularda HSK patogenezi ve gelişme riski henüz belirsizdir. Bu nedenle, DEA'lar ile tedavi edilen sirozlu hastalar tedavi sonrasında yakın aralıklarla takip edilmelidir.

Anahtar sözcükler: Hepatit C virüsü; hepatosellüler karsinom; ledipasvir; sofosbuvir.

Hepatocellular carcinoma (HCC) is the fifth most frequently diagnosed cancer and the second most common cause of cancer-related death in the world. ${ }^{[1]}$ Chronic hepatitis $\mathrm{C}(\mathrm{CHC})$ infection is one of the most common causes of cirrhosis worldwide, keeping in mind that HCC can develop without developing cirrhosis in $\mathrm{CHC}$ cases. In this article, we present a female patient with $\mathrm{CHC}$ genotype $1 \mathrm{~b}$-induced compensated cirrhosis who was treated with ledipasvir/sofosbuvir combination. One year following the treatment, she was found to have a giant HCC in the right lobe of liver without virus reactivation.

\section{CASE REPORT}

The patient is a 58-year-old female with past medical history of $\mathrm{CHC}$ infection, cholecystectomy, urolithiasis, and ovarian cyst operation. She had 


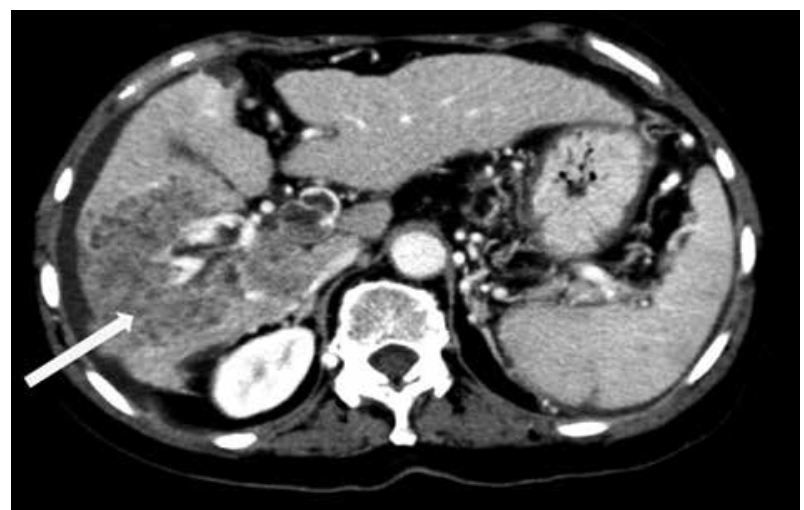

Figure 1. Giant hepatocellular carcinoma lesion in right lobe of liver in computed tomography scan.

no information about how she acquired hepatitis $\mathrm{C}$ virus. She denied suspicious sexual intercourses, intravenous drug use, and/or tattoo history. She had no history of alcohol consumption either. She had $\mathrm{CHC}$-induced compensated cirrhosis, and the combination of pegylated interferon and ribavirin treatment was unsuccessful several years ago. She applied to our liver transplantation unit three years ago with compensated liver cirrhosis without HCC. Her model for end-stage liver disease (MELD) score was low and alpha-fetoprotein levels were normal; hence, transplantation was delayed. Follow-up at three-month intervals was established, after which the patient was observed at another medical center during the following three years. She had ledipasvir/sofosbuvir therapy for three months at this center a year ago, after which the patient did not apply to any facility for follow-up. The patient applied with the complaints of weakness and weight loss to the external medical center, after which a giant HCC was detected on portal computed tomography (CT) scan in the right lobe of the liver. Patient was referred to our hepatobiliary diseases unit for treatment. We performed a panel of laboratory tests, CT scans, dynamic abdominal magnetic resonance imaging (MRI), and positron emission tomography. Her alpha-fetoprotein level was $63.315 \mathrm{ng} / \mathrm{mL}$, hepatitis C virus (HCV) ribonucleic acid (RNA) was negative, and liver transaminase levels were within the normal range. A giant HCC lesion almost completely filling the right lobe was observed. She had also a satellite HCC nodule in the left lobe of the liver with a diameter of approximately $3 \mathrm{~cm}$. Portal vein thrombosis associated with the HCC was observed

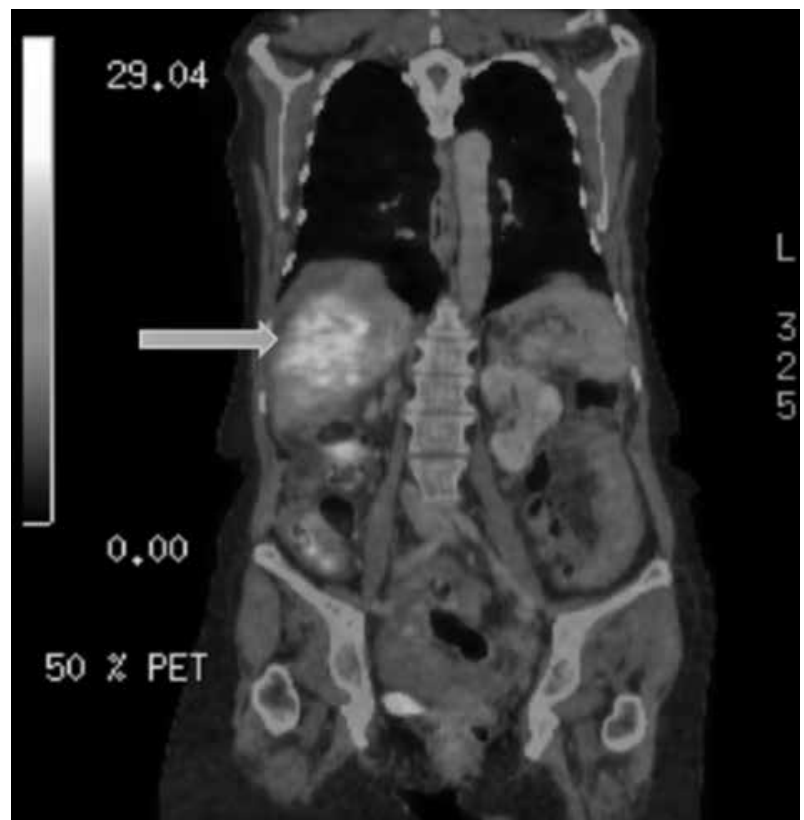

Figure 2. Giant hepatocellular carcinoma lesion on the right lobe of liver in positron emission tomography/ computed tomography scan.

on abdominal imaging and she was out of the Milan criteria for liver transplantation. The patient was found inoperable for transplantation at the liver transplantation council and referred to the medical oncology council, who decided to perform trans-arterial radioembolization treatment for the patient (Figure 1 and 2). A written informed consent was obtained from the patient.

\section{DISCUSSION}

Hepatitis $\mathrm{C}$ virus is a hepatotropic RNA virus estimated to infect approximately 71 million people worldwide. Hepatitis $\mathrm{C}$ virus can be the cause of chronic hepatitis, liver cirrhosis, and HCC. ${ }^{[1]}$ In patients with untreated CHC, 20\% of cases progress to cirrhosis, while $1-4 \%$ of them develop HCC. ${ }^{[2]}$ Over the past few years, several direct-acting agents (DAAs) have been developed that target some proteins in the critical stages of the HCV lifecycle. Combination of two or three DAAs can totally cure $\mathrm{CHC}$ infection in $95 \%$ of genotype 1 patients. ${ }^{[3]}$

Side effects of DAAs are controversial, particularly in cirrhotic cases. The number of cases described to develop HCC after treatment with DAAs in the literature is increasing. According to current knowledge, HCC development 
mechanisms are quite complex. The etiology of HCC includes multiple mechanisms, while the presence of liver cirrhosis is a key factor for the development of HCC. ${ }^{[4]}$ Hepatitis $\mathrm{C}$ virus also has the potential to stimulate oncological pathways, regardless of cirrhosis. Treatment with DAAs leads to a very rapid decrease in HCV RNA levels. Rapid and sudden disappearance of chronic inflammation due to chronic hepatitis may lead to rapid and uncontrolled proliferation of hepatocytes or stimulate some unknown oncological pathways which may lead to HCC development.

Direct-acting antivirals are suggested for patients with MELD score of lower than 12 in cirrhotic patients; however, the relationship between HCC development and DAAs is unclear. Even if $\mathrm{HCV}$ is fully eradicated, the risk of developing HCC continues in patients with cirrhosis. Thus, these patients should be closely monitored at intervals of 12 weeks or less after the treatment.

\section{Declaration of conflicting interests}

The authors declared no conflicts of interest with respect to the authorship and/or publication of this article.

\section{Funding}

The authors received no financial support for the research and/or authorship of this article.

\section{REFERENCES}

1. Polaris Observatory HCV Collaborators. Global prevalence and genotype distribution of hepatitis $C$ virus infection in 2015: a modelling study. Lancet Gastroenterol Hepatol 2017;2:161-76.

2. El-Serag HB. Hepatocellular carcinoma. N Engl J Med 2011;365:1118-27.

3. Webster DP, Klenerman P, Dusheiko GM. Hepatitis C. Lancet 2015;385:1124-35.

4. Soliman MS, Soliman YY, Ahmad Q, Yarlagadda R. An unfortunate failure: multifocal hepatocellular carcinoma in a non-cirrhotic patient with chronic hepatitis $C$ treated with ledipasvir/sofosbuvir. J Community Hosp Intern Med Perspect 2018;8:167-9. 